\title{
NETWORKING BASE OF SPORTS FACILITIES IN THE ORDER OF THEIR PRESENTATION TO A WIDER AUDIENCE
}

\author{
Sretenka L. Dugalić \\ Singidunum University, \\ Faculty of Physical Education \& \\ Management in Sport \\ 32 Danijelova Street, Belgrade, Serbia
}

\begin{abstract}
:
This paper seeks to examine and highlight the importance of modern electronic communication with the widest sports audience in order to speed up traffic and capacity utilization of the sports facility. The state, country, owners, professional managers, athletes, sponsors and visitors benefit from transparent high-quality and comprehensive network of sports facilities. The required information in this communication spectrum includes the capacity of sports facility, especially the field of play and content for visitors, diversity of programs it offers, spectacles that encourage interest of visitors, the quality and comfort of accommodation, security, location, history (tradition), design, decor, club colours and the like. Serbia does not have a single database of their valuable property in the system of sports. The Rule on the national categorization of sports facilities in 2013, and the Strategy of development of sport in the Republic of Serbia 2014-2018, provided the evidence established by the end of 2016. It could be useful for commercialization and practice to make it in electronic, standardized form. This would increase the chances of obtaining the championship, which would justify the mission to build sports facilities and their existence, and multiple maximizing the economic and other benefits.
\end{abstract}

Key words:

management of sports facilities, sport standardization, the categorization of sports facilities, electronic register of sports infrastructure.

\section{INTRODUCTION}

According to the Sports Act (2016, Article 145), sports facilities are arranged and equipped surfaces and facilities for the performance of sports activities. Sports facility, in addition to space intended for sports activities, may have content (sanitary, dressing, storage, stands, etc.), and installed equipment (construction and sports). The Rulebook on Precise Requirements to Performing Sport Activities and Sport Business (2013) assumes that sports organizations must have adequate space (facility). The space and facilities requirement (according Article 6) in which they organize competitions must fulfil the safety standards (Article 7). It has at least one visitors first-aid room (Article 8), and must allow visitors with disabilities to watch an event in the sport facility, in the same way as the rest of visitors (Article 9). The provisions of the Sports Act and the Rules have been transfused into a strategy (Strategy for Development of Sport in the Republic of Serbia for the period 2014-2018). It is estimated in part 
3.5., of the strategy (sports facilities) that many sports facilities, primarily because of inadequate management and maintenance in times of crisis, have very poor conditions. Therefore, there is a great need for revitalization of existing and constructing of new sports facilities. But the strategy provides an improvement of their capacities as well as building of new facilities. Action Plan for the Implementation of the Strategy of Development of Sports in the Republic of Serbia 2014-2018, defined two broad goals relating to the creation of conditions for systematic planning of the construction and renovation of sports facilities and financing, as well as work on building national training centers. Sports Act provides that on the basis of the analysis of the current situation, the Republic Institute for Sport performs the categorization of sports facilities in order to define priorities in the planning of reconstruction and construction of the sports facilities. According to the Rule Book on National Categorization of Sports Facilities (2013), the goal is standardization and quality management of content of facilities it has and offers to visitors. The deadline for registration and creation of a unique register of sports facilities is the end of 2016, but only $60 \%$ has been done (Danas Conference Center, 2015).

The facility management is a process that involves (Dugalić, 2007) 1 / planning construction and operation of the sports facility, 2 / finance the construction and ongoing operations, 3 / sports organization (training, competition) and business (maintenance, etc.), 4 / management of sports facilities, 5 / marketing management, and 6 / control operations (security, risk management, etc.). Therefore, the management of the sports facility includes: a strategic approach of facility, and business (serviscape), which is also called operations management of the sports facilities. It is important to understand the two root concepts - facility management and operations management in order to effectively understand sport facility operations management. Facility management is an all-encompassing term referring to the maintenance and care of commercial and non-profit buildings, including but not limited to sport facilities, including heating, ventilation, and air conditioning (HVAC); electrical; plumbing; sound and lighting systems; cleaning, grounds keeping, and housekeeping; security; and general operations. The goal of facility management is to organize and supervise the safe and secure maintenance and operation of the facility in a financially and environmentally sound manner. Schwarz, Hall, \& Shibli, 2010, 3).

The management of sports facilities effects allotment scientific discipline of sports management in accordance with the requirements of a modern sports practice
(Parks, Zanger, \& Quarterman, 1998, Fried, 2005; Mašić 2006). According to Farmer, Mulrooney \& Ammon (1996), the management of the sports facility covers an issues: planning, construction, financing, maintenance, facility management operations and marketing. The emphasis is on the design of sports and entertainment complexes with the elements such as 1 / court, 2 / parking, 3 / position and orientation (toward to the latitude and major roads), 4 / sports facility capacity (measured by overall dimensions and by court in $\mathrm{m} 2, \mathrm{~m} 3$, etc.), 5 / outdoor traffic flow (ramps and connection to public roads), 6 / internal traffic flow (horizontal and vertical movement of people and supplies - movement in the facility and between the level of the stands), 7 / VIP personality booths, 8 / sales area, 9 / toilets for visitors, 10 / marks that guide the visitors, 11 / security and safety (members of the public order, marshals, medical and emergency assistance, anti-fire protection, etc.), 12 / stands, 13 / space for players (measurement procedure, dressing room, media room..., with direct connection with a court), 14 / media space devoted to reporters, 15 / score and public adveretising screens, and 16 / space for administration, operations and maintenance (Dugalić, Krsteska, 2013). These elements must be included in the computer display offers of sports facilities. The infrastructure criteria is required by international sports associations, to achieve and maintain sport competitive advantage. Marketing is a good reason, because the integrity of the content and comfort increase the chances of obtaining the championship taking place in them. There are different sports legal frameworks and standards for infrastructure criteria in the world (Mašić et al., 2011). There are also more sites in America that present a content of stadiums which are different in size and other. Below is an outline of their websites that present the network base of sports facilities in a transparent manner (Figure 1, 2, 3).

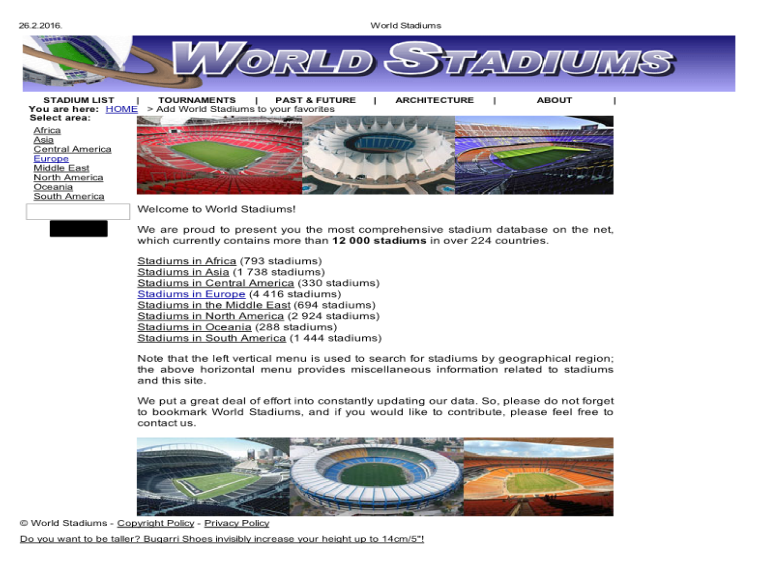

Figure 1. The World Stadium (www.worldstadiums.com) 


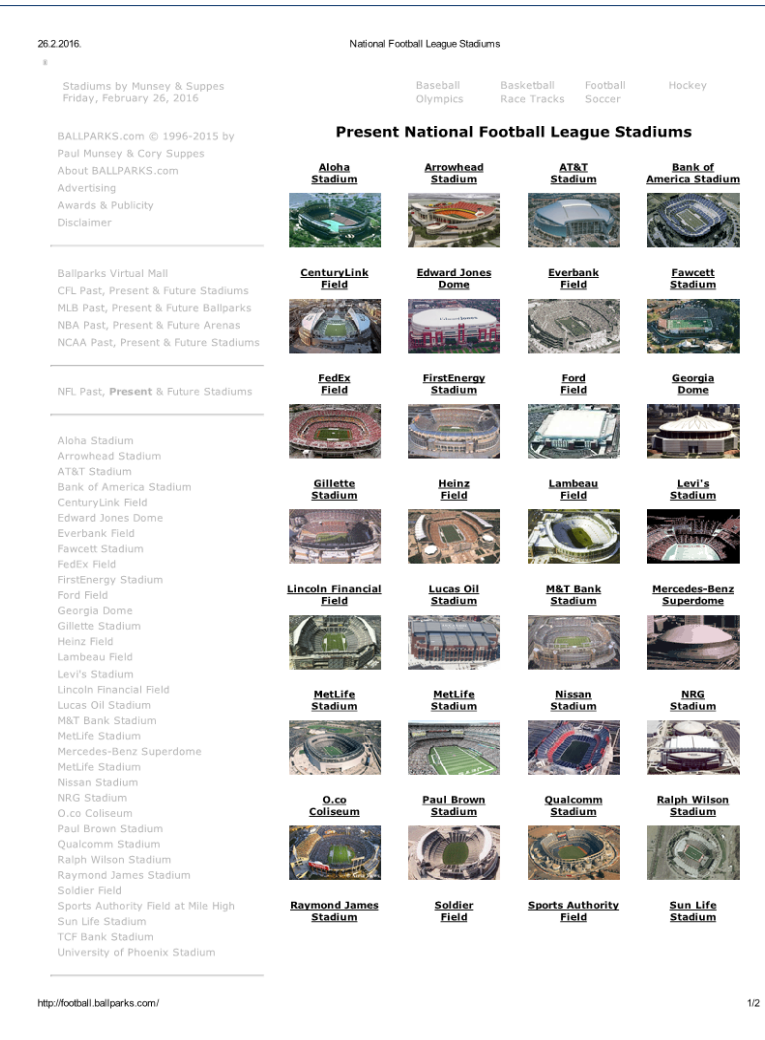

Figure 2. The Americans stadiums by Munsey \& Suppes, World Soccer Stadiums/Football Pitches, http:// football.ballparks.com.

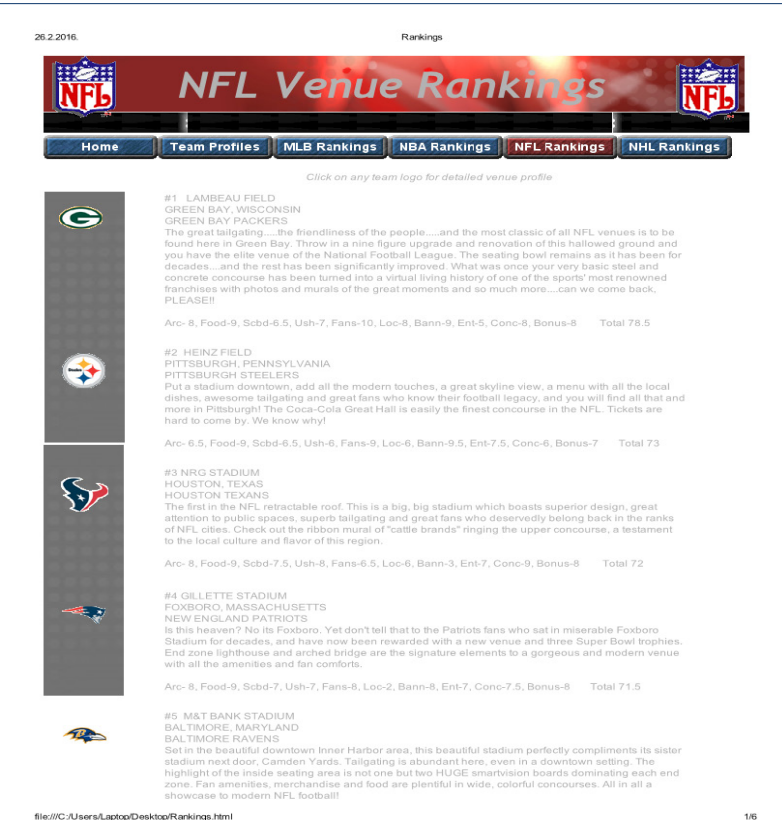

Figure 3. Categorization of American Stadium to the Kulyk, A., \& Farrell, P. (2015).

For example, Union of European Football Associations (UEFA) has published a multilingual guide which sets down the requirements for stadium design and construction, so as to assist Europe's member associa- tions in helping raise standards. It provides support to members by making a free cession type projects for the construction of the stadium (UEFA, Guide to Quality Stadiums, 2015), carried out categorization and record stadiums that meet the standards in a unique database (Fig. 4).
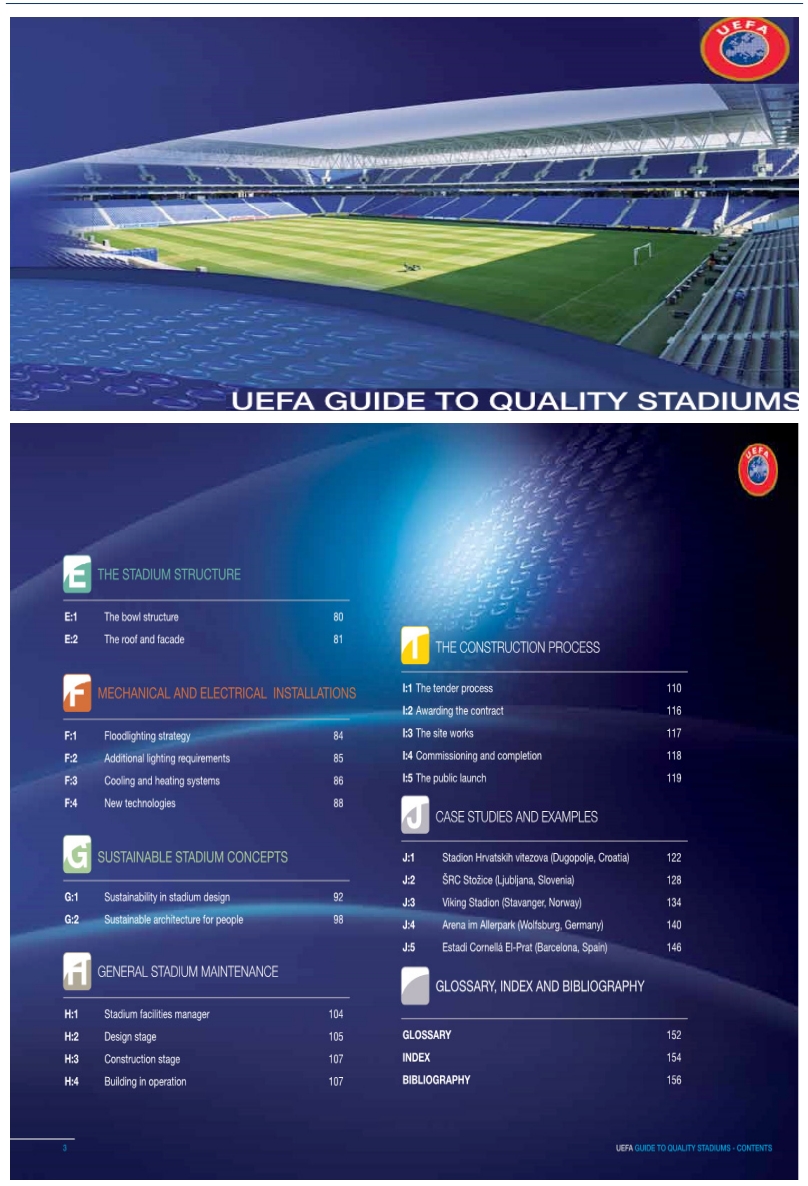

Figure 4. UEFA Guide to Quality Stadiums

\section{INTERNATIONAL PRACTICE}

According to the Schwarz, Hall, \& Shibli $(2010,4)$, there are numerous associations that oversee the profession of facility management worldwide. These associations have further clarified the definition of facility management and also provide guidance and education for those who are employed in the field. The world's largest and most widely recognized international association for professional facility managers is the International Facility Management Association (IFMA). According to their website (www.ifma.org, Figure 5), they support more than 19,500 members in 60 countries through 125 chapters and 15 councils. They define facility management as 'a profession that encompasses multiple disci- 
plines to ensure functionality of the built environment by integrating people, place, process and technology', and further clarify this definition as 'the practice or coordinating the physical workplace with the people, and work of the organization; integrates the principles of business administration, architecture, and the behavioral and engineering sciences'.

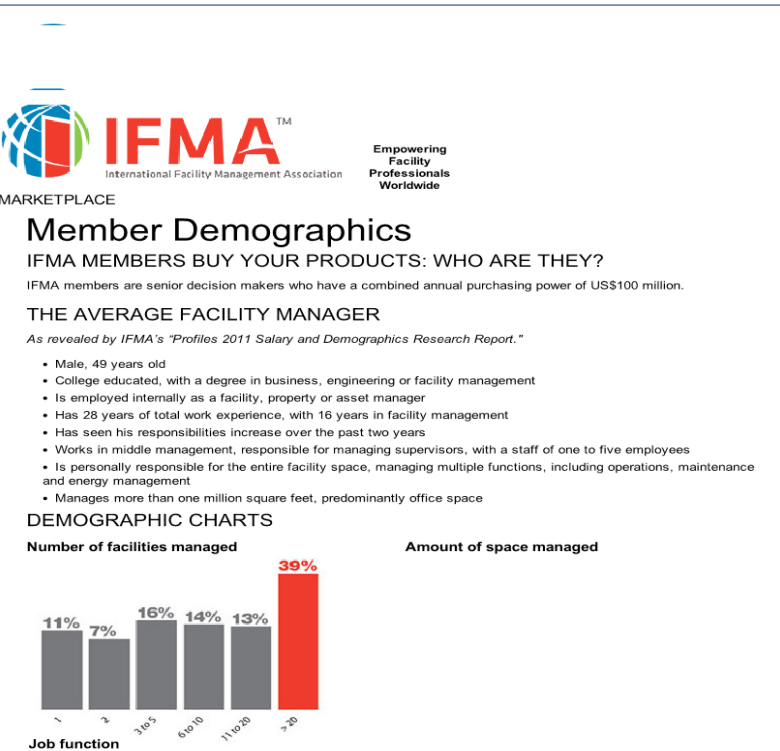

Figure 5. Demographic profile of sports facility manager (www.ifma.org)

Other organizations include the British Institute of Facilities Management (BIFM, www.bifm.org.uk), the Facility Management Association of Australia (FMA Australia, www.fma.com.au), and the International Association of Assembly Managers (IAAM, www.iaam. org). While facility management focuses on the overall maintenance and care of a building, operations management focuses on administrating the processes to produce and distribute the products and services offered through a facility. This would include the processes of production (tangible and intangible), inventory control, supply chain management, purchasing, logistics, scheduling, staffing, and general services - with the goal of maintaining, controlling, and improving organizational activities. The operations management field also has numerous associations that support the profession. The largest is the Association for Operations Management (APICS, www.apics.org), whose mission is to build knowledge and skills in operations management professionals to enhance and validate abilities and accelerate careers. Other organizations that support the profession of operations management globally include the Euro- pean Operations Management Association (EurOMA, www.euroma-online.org/), the Production and Operations Management Society (POMS, www.poms.org), the Institute of Operations Management (www.iomnet.org. uk), etc.

\section{SPORT FACILITIES IN SERBIA}

National categorization of sports facilities requires establishing a criteria and standards for the categorization of sports facilities on the basis of the type of sports activity, technical characteristics of the sports facility and the level of competition for which meets the requirements (Sports Act, IV. Categorization in sports, article 139, paragraph 5). It shall be established on the basis of the Republic Institute of Sports that annually conducts the ranking, or categorizing for a period of 5 years (article 140).

According to the type of space in which to carry out sports facilities may be: 1) indoor sports facilities; 2) outdoor sports facilities. Sports facility is classified according to the predominant type of surface space if contents both, indoor or outdoor court. Indoor sports facilities are facilities that represent physical, functional, technical and technological unit with all installations, facilities and equipment intended to perform certain sports activities (halls, swimming pools, balloons, etc.). Outdoor sports facilities are specially designed areas dedicated to the performance of certain sporting activities (jogging trails, ski slopes, hiking trails and pedestrian paths, bike route, beaches, etc.).

Exceptionally, for the purpose of carrying out the training and implementation of competition and public road, river and lake are considered to be open sports grounds (outdoor), in accordance with the Sport Act (Article 146).

Sports facilities of national importance are facilities that have national and representative role in the development of sport and preservation of sport values. Status sports facility of national importance is acquired by an Act of the Government, at the proposal of the Ministry and after obtaining the opinion of the Serbian Olympic Committee, the Sports Association of Serbia and the Republic Institute of Sport (Article 147).

Management should be implemented and network of database structured at least in these facilities. The Article 148 stipulates that such a sports facility may revoke 
the status of the object of national importance if it is: not used to carry out sports activities and sports business, and the realization of the goals of sports, not held in a manner that allows the appropriate level of performance of these activities and operations, and does not ensure safe use. The Government regulates the conditions, criteria and manner of acquisition, or withdrawal of sports facility categorized by state.

Unfortunately, there are numerous contradictions in domestic sport practice. Database of sports facilities have been made by several business entities (cities, associations and for-profit organizations create their own database). So, databases are incomplete, inaccurate, non-transparent, and thus not correspond to the demands of modern sport. There is no unique database of the most valuable state properties and equipment. It is not certain to become the categorization of sports facilities is completed on time.

Some of the websites that published partial data are presented in Figures 6,7 and 8.

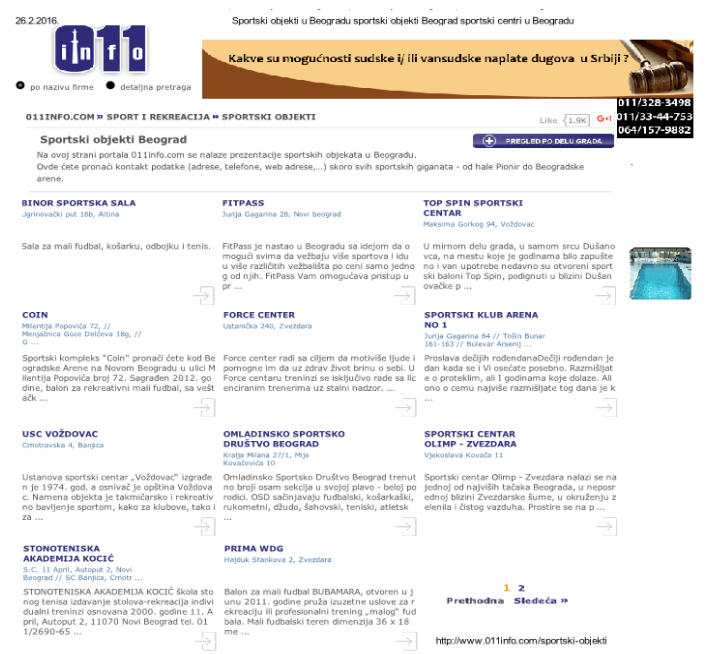

Figure 6. Sports facilities, Belgrade, www.011info.com/sportski-objekti.

The website of the Association Sports Centers of Serbia registered 36 sports centers (www.ascs.co.rs). These data can be downloaded from the website Sports facilities, halls and gyms - Serbia, My City (http://www. mojgrad.rs/Sport-i-rekreacija/Sportski-tereni-hale-idvorane), as shown Figure 7.

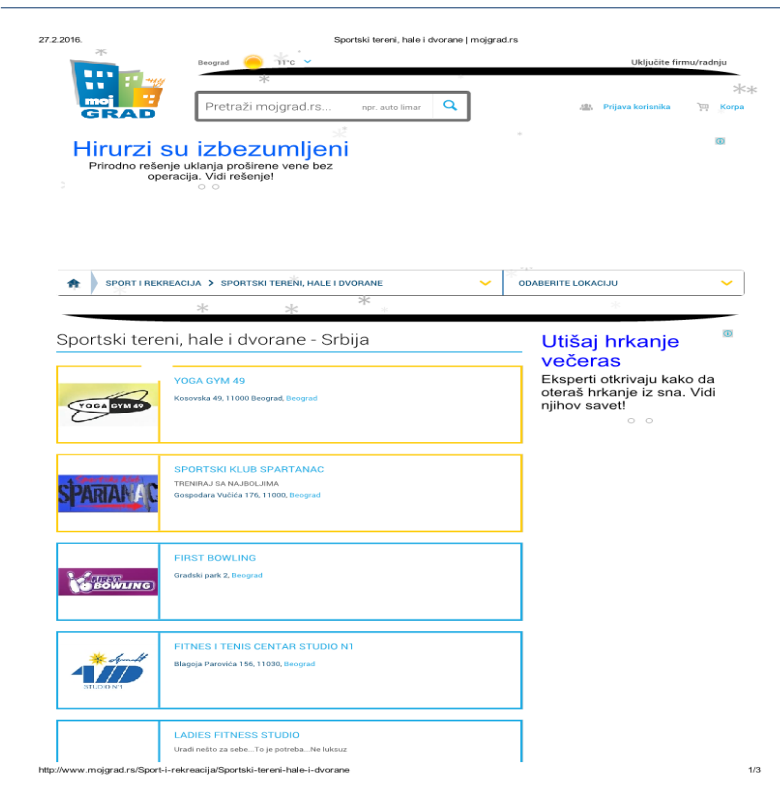

Figure 7. Sports court, halls and indoors - Serbia, My City, www.mojgrad.rs/Sport-i-rekreacija/Sportskitereni-hale-i-dvorane.

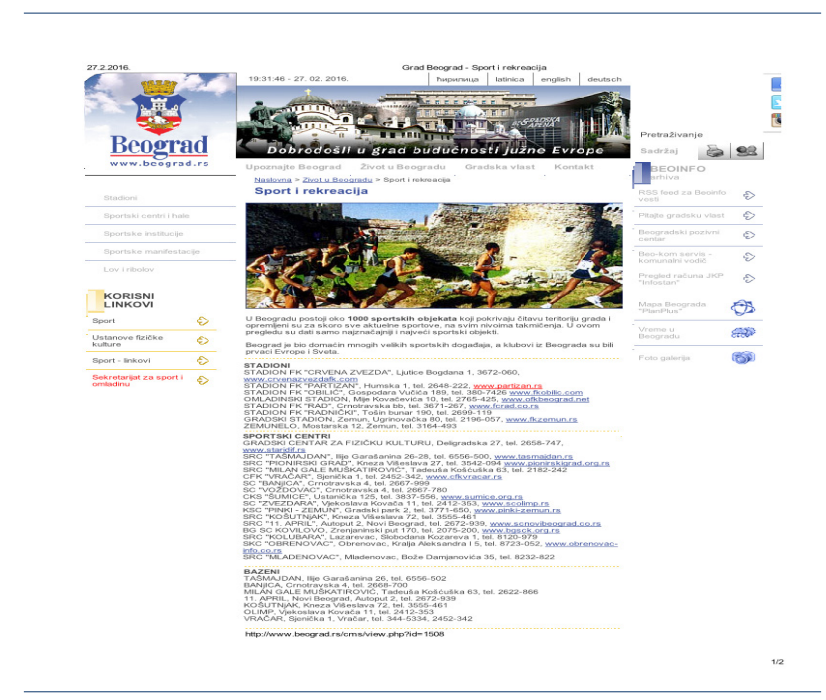

Figure 8. Belgrade City, Sport \& Recreation.

\section{CONCLUSION}

According to Article 152 of the Sports Act, the owner or users of sports facility are required to: 1 ) to be used in accordance with the rules and purpose of the facility, including the provision of the using certificate; 2) to maintain it in good condition and ensure proper sanitary and hygienic conditions; 3 ) doing action that allow, prevent or reduce the risk of damage to users (and others), and affect the increased risks too. Construction, reconstruction and maintenance of the sports facilities must be in compliance with the acts of the country, as well as relevant international and national sports associations' 
rules. This means that business in sports facility must be standardized according to the latest scientific achievements in the management and internet technology. The recording of these valuable state assets must also be according to the stated goals, strategy and action plan in the country.

The paper presents the experience of developed countries in managing the network database of sports facilities. Serbia needs a similar registry by a professional computer network, to achieve greater exposure, image and sales of naming rights. Through the web site, international associations provide legislative, technical, engineering and consulting support to its members. These organizations perform licensing, training for facilities management, and publish a list of jobs. Serbian practice seems poor in compared to the foreign experience. So, it is recommended make a database of sports facilities in electronic format via unique network, in accordance with the latest achievements of modern sports practice.

\section{REFERENCES}

Akcioni plan za sprovođenje strategije razvoja sporta u republici Srbiji za period 2014-2018 [The Action Plan for the Implementation of the Strategy for Development of Sport in the Republic of Serbia 2014-2018]. Retrieved November 14, 2015 from, http://www. oks.org.rs/wp-content/uploads/Akcioni-plan-zasprovodjenje-Strategije-

Danas Conference Centar. Sajam Ekonomija sporta [Sport Economy Fair]. Retrieved November 14, 2015 from www.danas.tv/drzava-ne-treba-da-gradi-ekonomski...

Dugalić, S. (2007). Menadžment sportskih objekata [Management Sport Facilities]. Beograd: Visoka sportska i zdravstvena škola.

Dugalić, S., \& Krsteska, A. (2013). Challenges of Sports Facilities and Project Management in XXI Century. Sport - Science \& Practice. Vol. 3(2), pp. 59-77.

Farmer, J. P, Mulrooney, A. L. \& Ammon, R. Jr. (1996). Sport Facility Planning \& Management. Morgantown: FIT, Inc.

Fried, G. (2005). Managing Sport Facilities. Champaign, USA: Human Kinetics, USA.

Grad Beograd, sport i rekreacija [Belgrade City, Sport \& Recreation]. Retrieved February 2, 2016 from www. beograd.rs/cms/view.php?id=1508.
International Facility Management Association. Member Demographic. Retrieved February 28, 2016 from www.ifma.org.

Kulyk, A., \& Farrell, P. (2015). The Ultimate Sports Road Trip. Retrieved November 14, 2015 from www.thesportsroadtrip.com.

Mašić Z., Đukanović, N., \& Šobat, M. (2011). Legal Responsibility In Management Of Sports Facilities in the USA. International Journal of Economics \& Law, Vol. 3, pp. 8292.

Mašić, Z. (2006). Menadžment sportskih objekata [Managing Sport Facilities]. Beograd: Fakultet za menadžment u sportu.

Parks, J., Zanger, B. \& Quarterman, J. (1998). Contemporary Sport Management, $2^{\text {nd }}$ ed. Champaign, IL: Human Kinetics Publishers.

Pravilnik o bližim uslovima za obavljanje sportskih aktivnosti i sportskih delatnosti [Rule Book on Precise Requirements to Performing Sport Activities and Sport Business], (Sl. Glasnik RS, [Official Gazette], $17 / 2013$.

Pravilnik o nacionalnoj kategorizaciji sportskih objekata [Rule Book on National Categorization of Sports Facilities], (Sl. Glasnik RS, [Official Gazette], 103/2013).

Schwarz, E., C., Hall, S. A., \& Shibli, S. (2010). Sport Facility Operations Management: A Global Perspective. Oxford, GB: Elsevier Ltd.

Sportski objekti [Sport Facilities]. 011INFO.COM. Retrieved February 1, 2016 from www.011info.com/ sportski-objekti.

Stadiums by Munsey \& Suppes. World Soccer Stadiums/ Football Pitches. Retrieved February 28, 2016 from http://football.ballparks.com/.

Strategija razvoja sporta u republici Srbiji za period 20142018 [Sports Development Strategy in the Republic of Serbia 2014-2018], (Sl. Glasnik RS, 1/2015).

The World Stadium. Retrieved November 11, 2015 from www.worldstadiums.com.

UEFA, Guide to Quality Stadiums. Retrieved November 2015 from www.uefa.org.

Zakon o sportu [Sports Act], (Sl. Glasnik RS, 10/2016). 